This item was submitted to Loughborough's Research Repository by the author.

Items in Figshare are protected by copyright, with all rights reserved, unless otherwise indicated.

\title{
Head teachers' perspectives on school drop-out in secondary schools in rural Punjab, Pakistan
}

PLEASE CITE THE PUBLISHED VERSION

http://dx.doi.org/10.1080/00131946.2017.1307196

\section{PUBLISHER}

(c) American Educational Studies Association. Published by Taylor \& Francis

\section{VERSION}

AM (Accepted Manuscript)

\section{PUBLISHER STATEMENT}

This work is made available according to the conditions of the Creative Commons Attribution-NonCommercialNoDerivatives 4.0 International (CC BY-NC-ND 4.0) licence. Full details of this licence are available at: https://creativecommons.org/licenses/by-nc-nd/4.0/

\section{LICENCE}

CC BY-NC-ND 4.0

\section{REPOSITORY RECORD}

Mughal, Abdul, and Jo Aldridge. 2019. "Head Teachers' Perspectives on School Drop-out in Secondary Schools in Rural Punjab, Pakistan”. figshare. https://hdl.handle.net/2134/23954. 


\title{
Head teachers' perspectives of the issue of dropping out from secondary schools in rural Punjab, Pakistan
}

\author{
Abdul Waheed Mughal and Jo Aldridge \\ Loughborough University, UK
}

\begin{abstract}
This study investigates head teachers' perspectives of the school dropout problem at public secondary schools in rural Punjab, Pakistan. The study is based on qualitative methods and included telephone interviews to collect primary data. Sixteen districts of the Punjab where secondary school dropout rate is above $20 \%$ were purposively selected for the study. The findings indicate that other than some socioeconomic and individual factors, different exam patterns at primary, elementary and secondary levels, easy promotion policy in early classes, English medium syllabus, poor educational background of students, high failure rate in class 9 and top-down pressures on teachers to perform non-academic duties are major causes of children dropping out from school. The findings of the study suggest that only through implementation of a socio-culturally compatible syllabus - a corresponding examination system for all levels - allowing students to repeat class 9 in case they fail, setting teachers free from non-teaching duties and providing extra financial support to poor students can significantly prevent school dropout at secondary level. The study further argues that easy promotion policy in early classes may retain more children at school but it causes high rates of dropout from secondary classes.
\end{abstract}

Key words: education, dropout, secondary schooling, rural areas, head teachers' perspective

\section{Introduction}

Despite national and international commitments to achieve the target of Universal Primary Education by 2015, about 58 million children are still out-of-school in disadvantaged and developing regions of the world; among them 29.6 million are in Sub-Saharan Africa, 9.9 million in West and South Asia and the remaining 18.4 million live in the rest of the world (UNESCO Institute for Statistics (UIS), 2014). In South and West Asian countries, the problem is most serious in Pakistan where 5.4 million primary school age children have never 
even entered a classroom. Globally, it is the second largest country in the world (after Nigeria) in terms of out-of-school children (UIS, 2014).

Out-of-school children are divided into two categories: dropped-out and never-enrolled. The focus of this study is on dropouts. The meaning of 'dropout' in the literature varies because of dissimilarities in regulations and schooling systems across the world. The issues of formal, non-formal, recognised and unrecognised schooling also make the dropout notion more complicated to define. The existing literature is characterised by a lack of an agreed-upon definition of the term 'dropout.' Generally, dropout is a concept assigned to those students who enrol but do not complete compulsory level schooling before attaining their legal school age. Schargel and Smink (2014) distinguish three types of dropouts: those who are leaving or have left school are referred to as 'dropouts'; those who are in school but detach themselves from learning are described as 'tune-outs'; and those who are suspended or expelled are termed 'force-out'. They further argue that the first category is easily categorised but the tune-outs are not obviously identifiable, whereas the force-outs are considered troublemakers both inside and outside school. Some alternative terms for dropout are: 'early school leaving' (Dekkers \& Claassen, 2001; Smyth \& Hattam, 2002); 'disengagement’(Rumberger, 1987) ; and ‘exclusion’ (Lee \& Breen, 2007; UNICEF, 2013).

There is no universal or unanimous definition of school dropout (Natriello, 1987). This is a highly contextual concept. A child may stop schooling for a certain time period or may never return to school. If he/she is willing to resume schooling at some time in the future, would this be called a dropout? What is the guarantee that he or she would resume formal schooling after dropping out? In the same way there are differences in basic or primary schooling between countries and the varied education systems make it harder to establish a common definition of a school dropout. Nonetheless, it is an established fact that early school leaving is intensifying the problem of out-of-school children around the world.

This study explored the dropout problem from public secondary schools through head teachers' perspectives in rural Pakistan. The head teachers are answerable to education authorities for low enrolment and high dropout rates, poor results, utilising funds and involving community members in school affairs. They remain engaged in managing school, staff, developing relations with local people and interacting with officials who ultimately design policies. Therefore, the head teachers are in a better position to understand and 
describe the dropout problem with reference to broader social and policy perspectives. The study addressed two basic research questions:

1- What are head teachers' views on why some students quit schooling during secondary classes?

2- How can the issue of dropping out be addressed effectively?

The article is divided into six sections. The first section provides a brief background to the issue of out-of-school children in an international context. The second section describes problems of school dropout in Pakistan and sets a rationale for selecting the province of Punjab for the study. The third section reviews the relevant literature on school dropout. The fourth section explores the methodology and research process. The fifth section discusses the findings of the study; and the sixth section concludes the findings and suggests policy measures to prevent children from dropping out from secondary schools in Pakistan.

\section{The Problem of School Dropout in Pakistan}

According to the Pakistan Economic Survey 2012-2013, the total population of the country is 184.35 million (69.87 million urban and 114.48 million rural). Out of the total population, 61.21 million are aged between 5 and 19; with young people making up the major part of society (Ministry of Finance, 2014). Pakistan is also a signatory of the World Conference on Education for All, 1990; the Dakar World Education Forum 2000; the Millennium Development Goal, 2000 and the UN Convention on the Rights of the Child, 1989 (UNICEF, 2013). The country has declared its constitutional responsibility to provide free and compulsory education to children aged five to sixteen. According to Article 25-A of the 18th Constitutional Amendment, 2010: “The State shall provide free and compulsory education to all children of the age of five to sixteen years in such a manner as may be determined by law” (National Assembly of Pakistan, 2012, p.15). This suggests that the state has taken responsibility to retain all children at school until they complete their secondary education at the age of sixteen. Thus, school dropouts in Pakistan are defined as those who leave before completing compulsory schooling with the intention to never to re-enrol at the same or another equivalent formal institution.

There is a huge gap between Pakistan's official commitments to educating every child until secondary level and the actual outcomes of school completion rates. The country not only has 
the second highest number of out-of-school children in the world but it also has a comparatively high dropout rate at an international level (Sawada, 1997). The problem of school dropout is serious in Pakistan as this phenomenon is visible at all school levels; rates vary from class to class and year to year throughout elementary education, but the drop out has been consistent at secondary schooling level for the last ten years. According to the Academy of Educational Planning and Management (AEPAM), total enrolment numbers in class 1 was 2,678,433 in 1999-2000, but only 27\% of children remained until class 10 in 2008-2009 (AEPAM, 2011). Similarly, in 2000-2001, 2,765,058 children enrolled in class 1 and only 27\% reached class 10 in 2009-2010 (AEPAM, 2012). In 2001-2002, the total enrolment in class 1 was 2,687,703 but only 27\% went on to class 10 in 2010-2011, i.e. 63\% children dropped out before completing compulsory secondary education (AEPAM, 2013). At present, out of the total enrolment in public schools, only $27 \%$ of students were enrolled until class 10 in Pakistan. These are alarming figures for the government and educational policymakers. The dropout rate is higher for secondary school children aged 14-16 compared to elementary level aged 11-13 students and primary level students aged 6-10 across the country. According to the Annual Status of Education Report (ASER), dropout rate at secondary level is $7.8 \%$ in urban areas and $14.5 \%$ in rural areas (ASER, 2014). Considering the educational challenges faced by the local community, this study is aimed at understanding the reasons for the high dropout rate at secondary level from the perspective of head teachers. Punjab, Sindh, Khyber Pakhtunkhwa and Baluchistan are the four provinces of Pakistan. Punjab has been selected for the study because it is the most populous province of the country. According to Pakistan Standards and Living Measurement (PSLM) 2010-11, the overall literacy rate in the province is $60 \%$; for males it is $70 \%$ and for females $51 \%$ (Pakistan Bureau of Statistics, 2011). The province of Punjab is divided into 36 districts: Lahore and Multan have been classified as urban and the remaining 34 districts come under the rural category (ASER, 2014). Considering Punjab is the most populous province of the country, it also bears a higher number of out-of-school children compared to the other provinces. The following table shows the numbers of out-of-school children aged 14-16 in rural Punjab in 2013. 
Table 1

Trends of out-of- secondary school children at district level, Punjab (rural), 2012

\begin{tabular}{|c|c|c|c|}
\hline No & Districts & $\begin{array}{c}\text { Children aged 14-16 } \\
\text { Never enrolled (\%) }\end{array}$ & $\begin{array}{c}\text { Children aged 14-16 } \\
\text { Dropped out (\%) }\end{array}$ \\
\hline 1 & Attock & 12.4 & 14.0 \\
\hline 2 & Bahawalnager & 12.2 & 28.4 \\
\hline 3 & Bahawalpur & 20.5 & 27.1 \\
\hline 4 & Bhakhar & 14.5 & 19.0 \\
\hline 5 & Chakwal & 3.9 & 7.4 \\
\hline 6 & Chiniot & 21.1 & 24.5 \\
\hline 7 & D.Ghazi Khan & 19.8 & 26.5 \\
\hline 8 & Faisalabad & 8.3 & 15.8 \\
\hline 9 & Gujranwala & 3.7 & 11.7 \\
\hline 10 & Gujrat & 0.7 & 11.3 \\
\hline 11 & Hafizabad & 6.9 & 17.2 \\
\hline 12 & Jehlum & 3.5 & 14.5 \\
\hline 13 & Jhang & 8.8 & 22.4 \\
\hline 14 & Kasur & 9.1 & 25.6 \\
\hline 15 & Khanewal & 10.4 & 20.7 \\
\hline 16 & Khushab & 15.6 & 14.6 \\
\hline 17 & Lahore & 5.1 & 16.1 \\
\hline 18 & Layyah & 8.3 & 15.0 \\
\hline 19 & Lodhran & 17.9 & 30.6 \\
\hline 20 & Mandi Bahuddin & 3.2 & 14.2 \\
\hline 21 & Mianwali & 10.1 & 19.2 \\
\hline 22 & Multan & 16.8 & 26.6 \\
\hline 23 & Muzaffar Garh & 10.4 & 20.6 \\
\hline 24 & Nankana Sahib & 8.3 & 11.5 \\
\hline 25 & Narowal & 1.8 & 12.0 \\
\hline 25 & Okara & 16.3 & 18.4 \\
\hline 27 & Pakpattan & 18.1 & 27.8 \\
\hline 28 & Rahim Yar Khan & 23.8 & 20.7 \\
\hline 28 & Rajanpur & 33.8 & 20.1 \\
\hline 30 & Rawalpindi & 7.7 & 4.5 \\
\hline 31 & Sahiwal & 12.4 & 15.8 \\
\hline 32 & Sargodha & 5.3 & 20.9 \\
\hline 33 & Sheikhupura & 3.5 & 14.1 \\
\hline 34 & Sialkot & 2.9 & 24.0 \\
\hline 35 & Toba Tek Singh & 9.2 & 14.1 \\
\hline
\end{tabular}




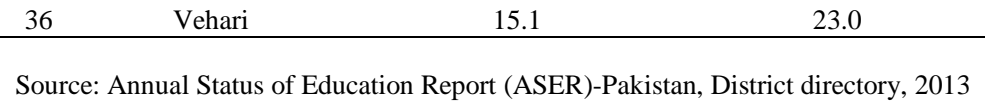

Table.1 shows the district breakdown percentages of never-enrolled and dropped-out children of secondary school age (classes $9 \& 10$ ) in rural Punjab. The table reveals that the dropout rate at secondary level is pervasive across the province. This rate is highest in the district of Lodhran (30.6\%); and the rate is above $20 \%$ in sixteen districts. It is at the lowest level in Rawalpindi (4.5\%), which is adjacent to the capital territory of Islamabad where the rural areas are more developed compared to the other regions. This could be a possible reason for the lower dropout rate. The high dropout rate indicates that Pakistan is less able to meet Clause 1(e) of Article 28 of the United Nations Convention on the Rights of the Child (UNCRC). This Article requires all signatories to reduce school dropout rates.

Dropping out from school causes a loss of the resources a state invests in its human capital development. Economically less developed countries like Pakistan have rarely had any alternate education and training programmes for school dropouts. Henceforth, the children who fail to complete secondary schooling face socioeconomic consequences in their future lives.

Children and young people make up a large component of Pakistani society. Completing compulsory schooling can contribute to individual well-being and to the socioeconomic development of local areas and the country as a whole. If students do not complete secondary education, they will have fewer future economic opportunities and the government's investment in their schooling goes to waste (Sabates, Akyeampong, Westbrook, \& Hunt, 2011). Dropping out from school can have negative effects on children and on local communities (Maton \& Moore, 2010). Dropouts may become involved in criminal activity if they are not attending school. Kronick and Hargis (1990) argue that it causes unemployment, physical/mental health problems and a higher crime rate. It also generates psychological problems such as the sense of losing self-esteem in society and the fear of fewer career opportunities in the future (Kaplan, 1983). Evidence has shown also that dropped out adults are more likely to use drugs (Mensch \& Kandel, 1988). Women or girls are more affected by this phenomenon, as it reduces their chances of employment and further educational opportunities (Ekstrom, Goertz, Pollack, \& Rock, 1986) and pushes them towards early motherhood (Mahler, 1999), bringing psychological and financial challenges (Kaplan, 1983). 


\section{School dropout in the literature: Teachers' and Head Teachers’ Perspectives}

Rumberger and Lim (2008) reviewed 25 years of research on school dropout in the USA and analysed 302 studies published on this issue by local and national institutions. They identified that the main factors associated with the dropout phenomenon were individual characteristics such as performance, behaviour, attitude, background; institutional characteristics such as family structure, resources and practices; and the school composition, its resources, structural features and policies. Kaplan and Luck (1977) argue that, "The dropout phenomenon is fundamentally rooted in the material and intangible conditions of poverty” (p. 45).

For the purpose of the current study, only findings from empirical research which included teachers and head teachers' perspectives have been included in the literature review. Generally, there is little published work on school dropout in Pakistan. This study examines a marginalized field of inquiry with respect to the reasons so many children and young people drop out from public secondary schools in Pakistan.

As stated earlier, research that has investigated the dropout phenomenon at secondary schools in Pakistan is largely missing. Hence, the literature review is based on studies conducted in other countries. In an international context, some empirical studies attempt to capture the dropout problem from schools through indirectly observing the behaviour of school staff while some others explore teachers' and head teachers' perspectives directly by asking questions (Abuya, Onsomu, \& Moore, 2012; Al-Hroub, 2014; Christle, Jolivette, \& Nelson, 2007; Dakwa, Chiome, \& Chabaya, 2014; Meyers \& Houssemand, 2011; Munsaka, 2011; Seidu \& Adzahlie-Mensah, 2010). Evidence from this literature shows that the teachers and head teachers do not tend to believe that teaching practices and the school culture push some students to leave early. Instead, they hold individuals, parents and other social factors responsible for children dropping out (Patterson, Hale, \& Stessman, 2007; Seidu \& AdzahlieMensah, 2010; Smyth \& Hattam, 2002). And yet it has been shown that students who come from disadvantaged and economically underprivileged backgrounds are often unable to meet the standards of an 'aggressive school culture' which sets high disciplinary standards for them (Smyth \& Hattam, 2002). As a result young people often leave school early.

“... if a school culture does not accept or respect the familial cultures of students and address the effective needs of students, reform efforts are not likely to improve academic performance or increase graduation rates” (Patterson et al., 2007, p.12). 
Although teachers generally did not recognise their role in the dropout problem, Seidu and Adzahlie-Mensah (2010) observed that this, along with other issues - absenteeism, late arrival at school, punishing students with a cane, wasting teaching hours in gossip and poor teaching practices - were all factors that contributed to the dropout problem in three rural Ghanaian schools. Teachers at schools with fewer dropouts appear to be more professional in their appearance, attitude, supervision and engagement with children as compared to those schools that have a high dropout rate (Christle et al., 2007). The positive relationship between students and teachers potentially lowers the dropout rate, yet to a large extent opportunities for building positive teacher-student relationships depends on the organizational and structural characteristics of schools (Lee \& Burkam, 2003).

Dakwa et al. (2014) studied poverty related causes for girls dropping out from school in rural Zimbabwe through teachers' and head teachers' perspectives. The researchers' found that poverty and health problems such as HIV and AIDS were the main reasons for dropping out. Other contributory factors included: inappropriate peer group, a negative attitude toward education, early marriages, a poor attitude in and outside of school, an unfriendly school environment, practices of corporal punishment and contradictions between formal schooling and religious beliefs. Although HIV and AIDs are not dropout risk factors in rural Pakistan, there is widespread fear of diseases such as dengue fever, which may influence young people’s decisions about dropping out.

Ahmad et al. (2014) reported a positive relationship between corporal punishment and dropout through their survey study of 300 primary school teachers in the Peshawar division of Khyber Pakhtunkhwa, Pakistan. Seidu and Adzahlie-Mensah (2010) also reported that the teachers acknowledged that physical punishment was not a useful approach to keeping students in school because it was having a negative effect on students' attendance. Some children stopped schooling because of fear of corporal punishment.

Other studies have shown that conflicts between school and home values can contribute to school dropout problems (Dakwa et al., 2014); as well as: a desire to earn money over the cost of schooling (Stephens, 2000); high school fees; poverty (Khan, Azhar, \& Shah, 2011; Stephens, 2000); child labour; low socioeconomic status; grade repetition; overcrowded classes; inadequate counselling services; early marriages and the lack of parental involvement in schooling (Abuya, Oketch, \& Musyoka, 2013; Al-Hroub, 2014; Bridgeland, 2010; G. A. Khan et al., 2011; Munsaka, 2011). Seidu and Adzahlie-Mensah (2010) found that the need 
for children to travel long distances to schools in rural Ghana was a further cause of dropout. In Khan and colleagues' 2011 study of school dropout in Pakistan, teachers reported that migration, age factors and lack of students' interest in studies all contributed to school dropout problems.

The available literature on school dropout in Pakistan is very limited. Existing studies on the issue have mostly been conducted by international researchers, who used household survey data to draw conclusions on school access, household characteristics and school dropout (Alderman, Behrman, Khan, Ross, \& Sabot, 1996; Alderman, Orazem, \& Paterno, 2001; Behrman, Ross, \& Sabot, 2008; Bilquees \& Saqib, 2004; Burney \& Irfan, 1991; Hazarika, 2001; Holmes, 2003; S. R. Khan, Siddiqui, \& Hussain, 1987; King, Orazem, \& Paterno, 2008; Lloyd, Mete, \& Grant, 2009; Yasayuki Sawada \& Loksbin, 2001; Yasuyuki Sawada \& Lokshin, 2009). Qualitative research on the school dropout problem is largely missing from the existing literature in Pakistan, particularly at secondary education level. This study is an attempt to fill the knowledge gap in this area.

\section{Research Methodology}

This section considers the methodological considerations employed in this research that focused on 16 rural districts of Punjab as case studies. Quantitative inquiry largely presents the researcher's point of view, whereas a qualitative methodology mostly seeks participants' perceptions (Bryman, 2012). Furthermore, qualitative research probes into a social or human problem and the researcher, “... seeks to listen to informants and build a picture based on their ideas” (Creswell, 1994, p. 21). In this study, the issue of school dropout was considered from the perspectives of head teachers; therefore, a qualitative research approach was the most appropriate method. Creswell further describes the qualitative paradigm as, “An inquiry process of understanding a social or human problem, based on building a complex, holistic picture, formed with words, reporting detailed views of informants, and conducting in a natural setting” (p. 4).

Teachers with experience of running or managing schools are better able to understand the dropout problem. Thus, exploring their views and perspectives is relevant and significant in understanding the school withdrawal phenomenon in rural Punjab. 
In the study sixteen rural districts of Punjab were selected for investigation where the dropout rate at secondary level was above 20\%. From the sampled districts, one male and one female head teacher was approached for interview from each district. School selection was based on two criteria: they were located in a remote rural area; and the head teachers were available and willing to be interviewed. Initially, the total number of participants was 32 (16 male and 16 female head teachers).

The study used telephone interview methods to collect the data, the rationale being to include all the diverse geographical locations of the sampled districts (Berg \& Lune, 2013) travelling around sixteen districts and approaching head teachers in 32 villages would not have been an easy task, especially given the remote locations of some of the schools. Furthermore, it was decided that telephone interviews would generate sufficient data relevant to the questions on the dropout problem. In addition, telephone interviews overcame obstacles relating to the participation of female head teachers in face-to-face interviews because of cultural sensitivities some female head teachers refused to be interviewed face-toface. Thus, the advantages of using telephone interviews outweighed some of the disadvantages - the potential to miss verbal clues, facial expressions, body language, and so on. However, telephone interview methods are useful when questions have already been specified in a semi-structured format (Berg \& Lune, 2013). Therefore, to make best use of the telephone interviews, the researcher (first author) prepared a set of semi-structured questions in advance. Nevertheless, he experienced that it was difficult to develop a social rapport with most of the rural female head teachers even over the phone.

\section{Research Process}

Sixteen sampled districts in Punjab where the secondary school dropout rate was above $20 \%$ were identified. Following comprehensive searches of the education profile of each district included in the sample (via the School Education Department of the Government of the Punjab website and from the researchers' own knowledge and further investigations of the schools in each area) one school from each subdivision was selected. Thus, the final sample comprised 32 schools (16 boys and 16 girls) and one informant (only the head teacher) from each school was approached to participate in the study. In this way the total informants consisted of 32 head teachers (16 males and 16 females). 
Previous qualitative studies on school dropout are limited to one particular community or geographical area, and investigate the dropout problem within certain communal contexts or locations. Their samples of study are also limited to only two to four schools (i.e., Abuya et al., 2013; Al-Hroub, 2014; Dakwa et al., 2014; Munsaka, 2011; Seidu \& Adzahlie-Mensah, 2010). By contrast, this study covers multiple locations and a larger number of schools, and thus provides a clearer picture of the dropout problem at secondary level compared to previous research studies.

Out of sixteen female head teachers only six agreed to a telephone interview. Some female head teachers were not willing to be interviewed. Thus, the final informants of the study consisted of 22 head teachers (16 males and 6 females.

A template was used to enable the researcher (first author) to listen and take notes during the telephone interviews listing some of the established reasons for school dropout and also allowing the researcher to elicit further information to develop a contextual understanding of the problem and, specifically, to explore reasons for dropout which had not been identified in previous studies.

Old and new themes were coded (thematically) separately. It is important to note that girls' high schools are managed and run only by female head teachers and boys' schools by male head teachers. Accordingly, head teachers' perspectives on school dropout were gender specific and these data were recorded and analysed separately. A manual coding scheme was used to cross-match the old and new themes and to analyse the entire data set.

\section{Results and Discussion}

Table 2 shows responses of male and female head teachers according to the questions asked about reasons for school dropout. The responses are reported in percentage. Where all participants gave the same response, it is indicated by $100 \%$. Thus, a percentage strategy is adopted while recording perspectives of the respondents. Here, it is significant to mention that each of the male and female head teachers had more than 15 years of teaching experience.

Table 2. Responses of male and female head teachers

\begin{tabular}{|l|l|l|}
\hline Research questions & Perspectives of female head & Perspectives of male head teachers \\
\hline
\end{tabular}




\begin{tabular}{|c|c|c|}
\hline & teachers & \\
\hline $\begin{array}{l}\text { What are the reasons } \\
\text { for pupils dropping out } \\
\text { of secondary school? }\end{array}$ & $\begin{array}{l}\text { Poverty (100\%) } \\
\text { Illiterate parents (60\%) } \\
\text { Parental lack of awareness of } \\
\text { importance of schooling (70\%) } \\
\text { Lack of parental interest ( } 80 \%) \\
\text { Different exam patterns (100\%) } \\
\text { English medium syllabus (100\%) } \\
\text { Poor academic background (100\%) } \\
\text { Large number of siblings- that } \\
\text { require looking after (60\%) } \\
\text { Early marriages (10\%) } \\
\text { Limited job prospects (50\%) } \\
\text { Unnecessary official pressure on } \\
\text { teachers (100\%) } \\
\text { Long distances to schools or exam } \\
\text { centres (20\%) } \\
\text { Household chores - pressure to } \\
\text { engage in domestic work at home. } \\
\text { (40\%) }\end{array}$ & $\begin{array}{l}\text { Poverty (80\%) } \\
\text { Lack of parental involvement/interest } \\
\text { ( } 80 \%) \\
\text { Lack of motivation (60\%) } \\
\text { Impact of peer group (60\%) } \\
\text { Limited prospects of employment (70\%) } \\
\text { Varied examination systems (100\%) } \\
\text { Easy promotion policy in early classes } \\
\text { (100\%) } \\
\text { English medium syllabus (100\%) } \\
\text { Influence of private schools (40\%) } \\
\text { Trends of Madrasah education (20\%) } \\
\text { Over-crowded classes (60\%) } \\
\text { Child labour- need for children to work } \\
\text { (40\%) } \\
\text { Poor educational background (90\%) } \\
\text { Failure in class } 9 \text { (100\%) } \\
\text { Too much supervision and monitoring of } \\
\text { teachers (100\%) } \\
\text { Excessive non-academic paper work } \\
\text { (100\%) } \\
\text { Uncaring/harsh attitude of teachers ( } 40 \% \text { ) } \\
\text { 'Soft' official policies for absentee/trouble } \\
\text { maker students ( } 70 \% \text { ) } \\
\text { Impact of a feudal system in remote areas } \\
\text { (40\%) }\end{array}$ \\
\hline $\begin{array}{l}\text { How can the issue of } \\
\text { dropping out be } \\
\text { addressed effectively? }\end{array}$ & 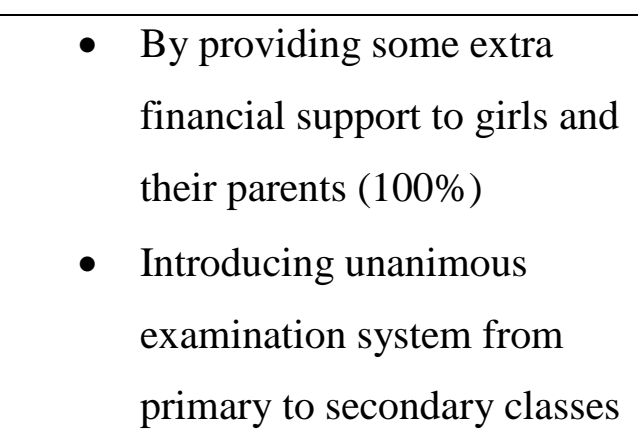 & $\begin{array}{l}\text { - } \text { By abolishing easy pass policy in } \\
\text { primary and elementary classes } \\
\text { (100\%) } \\
\text { - Introducing unanimous } \\
\text { examination system from primary } \\
\text { to secondary classes (100\%) }\end{array}$ \\
\hline
\end{tabular}




\begin{tabular}{|l|l|l|l|}
\hline $\begin{array}{l}\text { (100\%) } \\
\text { Medium of instruction shall } \\
\text { be the choice of students } \\
\text { rather than imposing on } \\
\text { them (100\%) }\end{array}$ & $\begin{array}{l}\text { Medium of instruction shall be the } \\
\text { choice of students rather than } \\
\text { imposing on them (100\%) }\end{array}$ \\
$\begin{array}{ll}\text { Free text books should be } \\
\text { provided in Urdu and }\end{array}$ & $\begin{array}{l}\text { Setting teachers free from non- } \\
\text { English (100\%) }\end{array}$ & $\begin{array}{l}\text { Allowing students to repeat class 9 } \\
\text { in case they fail (100\%) }\end{array}$ \\
Setting teachers free from & $\begin{array}{l}\text { Unnecessary supervision and } \\
\text { non-teaching duties (100\%). }\end{array}$ & $\begin{array}{l}\text { monitoring of teachers should be } \\
\text { stopped (100\%) }\end{array}$ \\
& $\begin{array}{l}\text { Extra funds should be provided to } \\
\text { prevent dropping out (100\%) }\end{array}$ \\
\hline
\end{tabular}

In the next section male and female head teachers' perspectives of the secondary school dropout problem in rural Punjab are discussed separately.

\section{Female head teachers' perspectives on the dropout problem}

As Table 2 shows, female head teachers described a range of reasons why children and young people drop out if secondary school.

Although the government provides free books and a Rs.200 (\$2) stipend per month to elementary and secondary students, this support was not considered sufficient by female head teachers for girls who were living in poverty to continue with their schooling. One head teacher from Muzzafar Garh reported:

Some girls are not even able to pay the Rs.20 (\$0.20) monthly tuition fee, and they have to work in the fields along with their parents to contribute to the household economy for the cost of their schooling. This badly affects their studies and eventually they drop out of school.

Furthermore, aggregate household poverty is a big hindrance to girls' education. Another female head teacher from Bhawal Pur district reported: 
The monthly stipend they receive from the government is usually used by the parents to buy the necessities of life instead of spending it on their children's schooling.

A head teacher from Multan district also identified this problem. She contended:

If the board exam centres are set up in another village or a nearby urban area, some parents cannot afford the cost of transportation or simply do not allow their daughters to go to remote exam centres on their own.

A big family is a common occurrence in rural areas; for many girls they have to look after their younger siblings after school and when their parents are at work. According to the female head teachers, excessive involvement in household chores and caring for siblings negatively affects girls' academic performance and their ability to attend school regularly; as a result, they often drop out of school. The previous studies on school dropout with teachers and head teachers' perspective also establish poverty, illiterate parents, lack of awareness, lack of parental interest, poor academic performance, a large number of siblings, early marriages, remote schools, household chores and caring for younger siblings as the main causes of school dropout for girls in underdeveloped areas of the world (i.e., Abuya et al., 2013; Al-Hroub, 2014; Bridgeland, 2010; Dakwa et al., 2014; G. A. Khan, Azhar, et al., 2011; Munsaka, 2011; Seidu \& Adzahlie-Mensah, 2010; Stephens, 2000). However, an English medium syllabus, varied examination patterns, easy promotion policy of the government, failure in class 9 and unnecessary official pressure on teachers emerged as new reasons for school dropout at secondary level in rural areas of Punjab.

All the female head teachers in this study reported that the government had provided science and maths books in English, as it had decreed that science subjects should be taught in English. However, staff and students were not prepared to teach or learn in English, and the introduction of an English syllabus was causing many girls to drop out. This new official policy did not match with the local culture and domestic learning environment. Although the government recruited some fresh graduates to meet the English teaching requirements in schools, they were not sufficient to cover all the classes. Rural students speak regional languages and it is often even difficult for them to learn in their national language (Urdu) and English is too difficult for them. The students have the choice in board exams to take the paper either in Urdu or English, but the government has provided free books to secondary students only in English, so there is a clear distinction between policy and practice. One head teacher from Rajan Pur district asserted: 
The poor students who cannot buy their own books in Urdu struggle with the English syllabus provided free of cost from the government and ultimately fail in exams, which cause them to drop out.

All the female head teachers reported that the failure rate was very high in class 9. In Pakistan, class 9 and 10 exams are separately conducted by the authorised secondary boards, and most of the students leave school after failing in class 9. This failure is an indication that they will not be able to complete the secondary school certificate and consequently dropout.

Thus, providing free text books and a Rs.200 monthly stipends to girls is not the only answer to the dropout problem at secondary level in rural Punjab as they have other educational needs linked to culture and social conditions and currently the government is not meeting these additional needs. Families also need more financial support to meet the hidden costs of schooling. All the female head teachers agreed that some extra financial support to girls and their parents could significantly reduce pupil dropout at secondary level.

The cultural contexts of early marriages of girls in rural Punjab are somewhat different from those reported by Munsaka (2011) in Zambia or Al-Hroub (2014) in Palestinian refugee camps in Lebanon, where parents are tempted by financial gains from bridegrooms. In most parts of Pakistan, and particularly in Punjab, parents offer a dowry to the suitors of their daughters. The female head teachers said that most of the parents arranged early marriages for their daughters for religious reasons, believing that once the girls reach the age of puberty they must get married.

Female head teachers also identified that non-official duties imposed on teachers by the government were contributing to the dropout problem. The government sets target for universal primary and secondary school enrolments, where teachers are required to visit doorto-door to convince parents to send their children to school. This requirement meant that many teachers spent a great deal of their time on community motivation activities, collecting data on out-of-school children in the area and recording their field activities on a daily basis, rather than teaching in school. Three different government departments continuously monitor school and staff progress, and if teachers cannot meet the academic and enrolment targets, their promotion and increments are stopped. Teachers' extra work (in communities, visiting parents etc) often came at the cost of their teaching activities and focus on their in-school students; as a result, some students failed their exams and ultimately dropped out of school. 
All the head teachers interviewed proposed strategies for preventing school dropout, such as making more money available to help girls from poor families to attend and stay in school, introducing similar examination patterns from primary to secondary classes, giving students a choice of selecting their medium of instruction and making teachers free from non-teaching official duties.

\section{Male head teachers' perspectives on the school dropout problem}

Fourteen out of the sixteen male head teachers contended that poverty was the main reason for school dropout at secondary level in rural Punjab. However, two had somewhat different opinions, arguing that it was not poverty but children's attitudes towards education which was the main problem. One of them reported that he had observed dropped out children and their parents using costly mobile phones, and argued that if they could afford expensive mobile phones they could also meet schooling costs but, according to this particular head teacher, children and parents did not have the right attitude toward education. The other head teacher made similar comments and blamed the parents and children who were not interested in education; rather, it was argued, they were making poverty an excuse for leaving school. However, their definition of poverty was limited and they measured it only by mobile phone usage when it is clear that poverty is multidimensional and cannot be judged through the possession of gadgets.

As Table 2 shows that apart from poverty, the male head teachers reported various reasons for pupil dropout at secondary school.

Almost all the head teachers were critical of the different examination systems at primary, elementary and secondary levels. The Punjab Examination Commission (PEC) conducts exams for classes 5 (primary) and 8 (elementary), whereas divisional boards for intermediate and secondary education organise exams for secondary and higher secondary school certificates. The head teachers maintained that the PEC widely use objective type questions in exams. Moreover, it promotes students to next level who obtain an overall 20\% mark or even fail in two to three subjects. An examination system that consists of short answers badly affects students' reading and writing abilities and they cannot develop the necessary academic capability for secondary level education. Some teachers also take this easy promotion government policy for granted and do not work sufficiently hard to teach the students. 
On the other hand, secondary school boards rely on a subjective examination system and observe a strict passing policy. At secondary level, it is compulsory for children to achieve a $33 \%$ mark in each subject to get a pass. If the student did not achieve advanced writing skills in their primary and elementary classes, they were less able to meet the requirements of secondary exams. Thus, a 'soft' promotion policy in early classes and variations in the examination system cause a large number of students to drop out during secondary education.

The English medium syllabus is another factor associated with failure in classes 9 and 10 . The female and male head teachers were largely agreed that students with a poor academic background could not cope with books in English and thus often dropped out of school; inconsistent government policies on the medium of education were also criticised by the head teachers during interview. For example, five years ago the government introduced a policy to teach maths and science subjects in English even at primary level across Punjab but it did not produce the desired results. The government has recently changed this policy and now from class one to three all subjects are being taught in Urdu. The male head teachers were also of the view that the English medium syllabus was not meeting the social, cultural and domestic environment of the children, and this was a further reason given for children dropping out of school. They also shared the feelings of the female head teachers regarding excessive and unnecessary monitoring of teachers and using them in non-academic activities outside of school.

Some male head teachers also complained about lack of staff and overcrowded classes. Discussing these issues during interview, one head teacher from the Pakpattan district said:

I am running a high school from class one to tenth. In primary section, I have 500 enrolled children but only two teachers. How two teachers can teach 500 students? Total enrolment at school is 700 and I have 10 teachers. I have to engage elementary teachers in the primary section. In this exercise, elementary students miss their lessons on daily basis which ultimately affect their studies and they fail in exams. This failure leads them to drop out.

Some head teachers reported that the influx of low quality private schools in rural areas was also contributing to the dropout problem at secondary level in the public sector. One head teacher from Khanewal district reported:

Most of the low quality private schools recruit untrained teachers and do not have enough academic facilities, as well as manipulating the examination system and 
following easy promotion policies to improve their results. When the students from low profile private institutions move to public schools for secondary education, they fail to show progress and eventually drop out.

Public schools have no prescribed admissions policy. They have to accept all students without taking admissions tests and regardless of children's educational background. Some government policies also play a part in the dropout problem at secondary level. For example, teachers' promotions and increments are based on examination results and meeting enrolment targets. One head teacher from the Sialkot district explained:

I had to struggle hard to meet the enrolment targets for my school as it took me a long time to develop social relations with the local community and win their trust. Although I was promoted to a higher official grade because of his performance, I was transferred to a remote area. This relocation disturbed my family and discouraged me from working hard. If I do not meet the enrolment targets at the new location, I could be demoted in the future.

Almost all the head teachers reported that the government was mainly focusing on enrolment whereas there was no policy in place to prevent dropout. The teachers were held responsible for enrolment and retention even though they did not have access to official and community support to meet enrolment and retention targets. They had to work as community motivators instead of teaching at school and felt that it was not their job to knock on every door in the area and convince parents to send their children to school; their job, they said, was to perform teaching duties at school. Some head teachers reported that sometimes parents became irritated when visited over and again by teachers sent to check up on them and monitor their children’s attendance at school.

Some head teachers also contended that under the immense official pressure of producing good results and keeping the failure rate at the lowest level, some schools intentionally encouraged students at risk not to sit the board exams and instead to apply as a private candidate. The boards of intermediate and secondary education allow students to take exams either as a regular or a private student. Students of public and officially recognised/affiliated schools are considered to be regular candidates, whereas private candidates have no formal association with any school; rather they take board exams on an individual basis. The majority of private candidates are dropouts, and a small number of them consist of students from non-formal institutions or who study privately. 
There are nine exam boards in Punjab, namely; Rawalpindi, Lahore, Multan, Sargodha, Gujranwala, Faisalabad, Bahawalpur, D G Khan and Sahiwal, apart from the Punjab Board of Technical Education, Lahore and the PEC. In order to investigate trends in private submissions in board exams, the records of the Board of Intermediate and Secondary Education (BISE), Gujranwala over two years were analysed. The Gujranwala Board consists of six districts, namely: Gujranwala, Gujrat, Hafizabad, Mandi Baha-udDin, Narowal and Sialkot. In 2013, a total of 208,883 candidates sat the annual exam for 9 class for the Gujranwala board, of which 48,081 (29.90\%) were private candidates (BISE Gujranwala, 2013). Similarly, 240,088 students sat the annual exam for class 9 class in 2014, of which 54,263 (29.20\%) were private candidates (BISE Gujranwala, 2014). The overall pass rate for the science group was $39.18 \%$ and for the general group $36.89 \%$ in the annual class 9 class exam held in 2013. Remarkably, the pass rate for the private candidates in the general group was higher $(37.42 \%)$ than that of the regular students (36.49\%) in the same year. However, in the science group it remained at $20.26 \%$ for the private candidates and $40.11 \%$ for the regular students respectively. It implies that regular students perform better in science subjects and private students in non-science subjects. The overall pass rate for both regular and private candidates at the class 9 Gujranwala board was 38.9\% in 2013. In this way 61.1\% students failed in class 9 in the Gujranwala board exams in 2013. The head teachers who were interviewed contended that the higher failure rate in class 9 discouraged students from completing their secondary education and therefore they often dropped out of school. They further reported that the students who failed in class 9 were not allowed to re-sit in the same class, rather they were forced to join class 10 . They were required to reappear in the failed subjects of class 9 along with class 10 annual exams. These students, who already had poor academic backgrounds, could not cope with class 9 and 10 subjects altogether and thus often dropped out of school.

However, candidates who passed board exams privately challenge the dropout definition, the figures and the differentiation between formal and non-formal schooling. The existing literature largely constitutes data from students dropping out within the formal school context. Nonetheless, there is evidence that a considerable number of students complete their secondary school certificate informally in Pakistan. The degrees issued by the boards have equal recognition in the job market regardless of whether they are gained privately or through established institutions. The success of private candidates also brings 
into question national dropout statistics. On the one hand, the withdrawal of these students from public schools adds to the official dropout figures, but on the other hand these students successfully complete secondary school education, appearing as private candidates in board exams. This distinction challenges the overall dropout rate at national level and makes it more complicated. Some dropped out students complete the secondary school certificate the same as attending pupils do. This trend raises the question of whether the dropout phenomenon should be linked to withdrawal from formal schooling or to appearing in a board exam as a private candidate. Therefore, the definition of 'dropout' needs to be revisited in Pakistan.

It is evident that sometimes school administration pushes underperforming students to drop out from school to keep the failure rate to a minimum. To overcome school tactics of discharging at-risk students from class 9, the government has recently imposed a nonpunishment and non-deregistration policy in public schools. The head teachers who were interviewed were of the view that this policy was also adding to the dropout problem. Trouble-making and habitual absentee pupils were not fearful of teachers; they simply took this policy for granted and thus frequently missed classes, remained absent from school for long periods, did not complete their homework and had no sense of accountability. The school administration could not take stern action against them and, as a result, they often failed in board exams and dropped out of school.

$50 \%$ of male head teachers said they believed that most students and their parents associated schooling with employment prospects. Students' concept of education was somewhat different. They considered education less as a source of personality and character building and more as a tool for economic survival. They linked school completion with job prospects. Unemployment of educated people in the area discouraged some pupils to complete secondary school certificate.

\section{Conclusion}

This study has identified new factors in the reasons for pupil dropout in secondary schools in Pakistan and some of these differ from the traditional push and pull theories as described in previous studies. This new evidence develops dropout theories further.

Previous studies on school dropout have considered the problem from a supply and demand perspective (Hunt, 2008) and have identified push-out/pull-out factors in school dropout rates (Jordan, Lara, \& McPartland, 1996). Generally, demand factors are linked to individual and 
family characteristics, whereas supply factors are the external ones related to school and community. Similarly, push-out factors are associated with the school environment and pullout factors ascribed to outside social pressures that conflict with educational objectives.

However, this study presents evidence that, along with push/pull and supply/demand factors, shows how government policies put undue pressure on teachers and often do not coincide with the socio-cultural environment of school, children, parents and community; these factors can also contribute to the school dropout problem. Sometimes adverse public policies also result in children dropping out of school. For example, government policies of introducing an English medium syllabus, using teachers as community motivators during school time, putting teachers under unnecessary monitoring, demanding needless paperwork, linking promotion and increments with school results and introducing capricious examination systems, not permitting class 9 failures to repeat the same class, are all contributing to the dropout problem at secondary level in rural Punjab. These policies are not only compromising the quality of education in Pakistan but they also result in large number of students leaving school before they have finished their education. In addition, the easy promotion policy prevalent in primary and elementary school classes across Punjab may help to keep more children in school but it increases the dropout rate at secondary level.

Education is commonly considered a means to enhance societal and individual wellbeing, and it has been declared and acknowledged as a basic human right. The world has witnessed some significant improvements in school enrolments in the last fifteen years (UIS, 2014). Generally, the focus of national and international policies has remained on increasing the total school enrolment rate in the last decade, whereas the problem of school dropout has received less attention. Evidence from three main international educational treaties (The World Conference on Education for All, 1990; The Dakar World Education Forum, 2000 and the Millennium Development Goals, 2000) demonstrates that high dropout rates, scarcity of sources, over-ambitious targets, donors' inability to fulfil funding promises, a lack of political commitment and civil partnership, ineffective policies and conflicts are the main obstacles in attaining Universal Primary Education targets. Because of these impediments, economically disadvantaged countries are unable to keep all their enrolled children in school. Furthermore, preventing dropout has not been a main policy driver in these treaties. For example, the Dakar Framework for Action sets some goals and strategies for achieving the objectives of Education for All, but no separate policy measure was suggested to prevent school dropout. 
The telephone interview method does not feature in qualitative studies of school dropout and this study is the first one to have used this method to understand the perspectives of head teachers regarding the school dropout problem at secondary level in a larger context by using multiple locations. Furthermore, the study confirms some traditional push-and-pull factors that are also highlighted in the existing literature school dropout. Additionally, it identifies that some public policies which do not match with the socio-cultural environment of the community also exacerbate the dropout problem. Therefore, only socio-culturally compatible policy interventions are useful to solve social problems like pupil dropout from school. Imposing an English medium syllabus on rural students presents a clear conflict or point of tension between the school and domestic environment. Moreover, a uniform examination system for all classes, allowing class 9 failures to repeat the same class, setting teachers free from non-teaching duties outside school, providing extra financial incentives to poor students, improvement in the quality of teaching and the introduction of fresh graduates into the schooling system could all help to significantly reduce pupil dropout out from secondary school in rural areas of Punjab. Dropping out from school is a serious problem across all economically poor states and universal targets of secondary education for all cannot be met until the issue of school dropout becomes a focus for policy at local and international level.

\section{References}

Abuya, B. a., Onsomu, E. O., \& Moore, D. (2012). Educational challenges and diminishing family safety net faced by high-school girls in a slum residence, Nairobi, Kenya. International Journal of Educational Development, 32(1), 81-91. http://doi.org/10.1016/j.ijedudev.2011.02.012

Abuya, B., Oketch, M., \& Musyoka, P. (2013). Why do pupils dropout when education is "free"? Explaining school dropout among the urban poor in Nairobi. Compare: A Journal of Comparative and International Education, 43(6), 740-762. http://doi.org/10.1080/03057925.2012.707458

AEPAM. (2011). Pakistan Education Statistics 2010-11. Academy of Education Planning and Management (AEPAM), Ministry of Professional and Technical Training Government of Pakistan, Islamabad.

AEPAM. (2012). Pakistan Education Statistics 2011-12. Academy of Education Planning and Management (AEPAM), Ministry of Professional and Technical Training Government of Pakistan, Islamabad.

AEPAM. (2013). Pakistan Education Statistics 2012-13. Academy of Education Planning and Management (AEPAM), Ministry of Professional and Technical Training Government of Pakistan, Islamabad.

Ahmad, I., Said, H., Awang, Z., Yasin, M. A.-M.-Z., Hassan, Z., \& Mansur, S. S. S. (2014). 
Effect of Self-efficacy on the Relationship between Corporal Punishment and School Dropout. Review of European Studies, 6(1), 196-200.

http://doi.org/10.5539/res.v6n1p196

Al-Hroub, A. (2014). Perspectives of school dropouts' dilemma in Palestinian refugee camps in Lebanon: An ethnographic study. International Journal of Educational Development, 35, 53-66. http://doi.org/10.1016/j.ijedudev.2013.04.004

Alderman, H., Behrman, J. R., Khan, S., Ross, D. R., \& Sabot, R. (1996). Decomposing the Regional Gap in Cognitive Skills in Rural Pakistan. Journal of Asian Economics, 7(1), 49-76.

Alderman, H., Orazem, P. F., \& Paterno, E. M. (2001). School Quality, School Cost, and the Public/Private School Choices of Low-Income Households in Pakistan. Journal of Human Resources.

ASER. (2014). Annual Status of Education Report (ASER) 2014. South Asian Forum for Education Development, Islamabad, Pakistan.

Behrman, J. R., Ross, D., \& Sabot, R. (2008). Improving quality versus increasing the quantity of schooling: Estimates of rates of return from rural Pakistan. Journal of Development Economics, 85(1-2), 94-104. http://doi.org/10.1016/j.jdeveco.2006.07.004

Berg, B. L., \& Lune, H. (2013). Qualitative Research Methods for the Social Sciences (8th ed.). Pearson Education Limited.

Bilquees, F., \& Saqib, N. U. (2004). Drop-Out Rates and Inter-School Movements: Evidence from Panel Data.

BISE Gujranwala. (2013). Gujranwala Board Result Gazette- 2013. Board of Intermediate and Secondary Education Gujranwala, Punjab, Pakistan. Retrieved from http://www.bisegrw.com/download/GAZETTE/Gz_MA2p13.pdf

BISE Gujranwala. (2014). Gujranwala Board Result Gazette- 2014. Board of Intermediate and Secondary Education Gujranwala, Punjab, Pakistan. Retrieved from http://www.bisegrw.com/download/GAZETTE/Gz_MA2p14.pdf

Bridgeland, J. M. (2010). The new dropout challenge: bridging gaps among students, parents, and teachers. New Directions for Youth Development, 2010(127), 101-10. http://doi.org/10.1002/yd.366

Bryman, A. (2012). Social research methods (4th ed.). Oxford University Press.

Burney, N. A., \& Irfan, M. (1991). Parental characteristics, supply of schools, and child school-enrolment in Pakistan. The Pakistan Development Review.

Christle, C. a., Jolivette, K., \& Nelson, C. M. (2007). School Characteristics Related to High School Dropout Rates. Remedial and Special Education, 28(6), 325-339. http://doi.org/10.1177/07419325070280060201

Creswell, J. W. (1994). Research design: Qualitative and quantitative approaches. SAGE Publications Inc.

Dakwa, F. E., Chiome, C., \& Chabaya, R. A. (2014). Poverty-Related causes of School Dropout- Dilemma of the Girl Child in Rural Zimbabwe. International Journal of Academic Research in Progressive Education and Development, 3(1), $233-242$. http://doi.org/10.6007/IJARPED/v3-i1/792

Dekkers, H., \& Claassen, A. (2001). Dropouts-disadvantaged by definition? A study of the perspective of very early school leavers. Studies in Educational Evaluation, 27(4), 341- 
354.

Ekstrom, R., Goertz, M., Pollack, J., \& Rock, D. (1986). Who drops out of high school and why? Findings from a national study. The Teachers College Record, 87(3), 356-373.

Hazarika, G. (2001). The Sensitivity of Primary School Enrollment to the Costs of PostPrimary Schooling in Rural Pakistan: A Gender Perspective. Education Economics, 9(3), 237-244. http://doi.org/10.1080/09645290110086117

Holmes, J. (2003). Measuring the determinants of school completion in Pakistan: Analysis of censoring and selection bias. Economics of Education Review, 22(3), 249-264. http://doi.org/10.1016/S0272-7757(02)00024-9

Hunt, F. (2008). Dropping Out from School: A Cross Country Review of Literature. CREATE PATHWAYS TO ACCESS Research Monograph No 16. University of Sussex.

Jordan, W. J., Lara, J., \& McPartland, J. M. (1996). Exploring the Causes of Early Dropout among Race-Ethnic and Gender Groups. Youth \& Society, 28(1), 62-94. http://doi.org/10.1177/0044118X96028001003

Kaplan, H. B. (Ed.). (1983). Psychosocial Stress: Trends in Theory and Research. Academic Press Inc.

Kaplan, J. L., \& Luck, E. C. (1977). The Dropout Phenomenon as a Social Problem. The Educational Forum, 42(1), 41-56. http://doi.org/10.1080/00131727709338151

Khan, G. A., Azhar, M., \& Shah, S. A. (2011). Causes of Primary School Drop out Among Rural Girls in Pakistan (No. 119). Sustainable Development Policy Institute Islamabad, Pakistan.

Khan, S. R., Siddiqui, R., \& Hussain, F. (1987). An analysis of school level drop-out rates and output in Pakistan. Research Reports Series No. 149. Pakistan Institute of Development Economics.

King, E. M., Orazem, P. F., \& Paterno, E. M. (2008). Promotion with and without Learning : Effects on Student Enrollment and Dropout Behavior (No. Policy Research Working Paper 4722). The World Bank.

Kronick, R. F., \& Hargis, C. H. (1990). Dropouts: Who Drops Out and Why-And the Recommended Action. Charles C Thomas Pub Ltd.

Lee, T., \& Breen, L. (2007). Young people's perceptions and experiences of leaving high school early: An exploration. Journal of Community and Applied Social Psychology, 17(5), 329-346. http://doi.org/10.1002/casp.887

Lee, V. E., \& Burkam, D. T. (2003). Dropping Out of High School: The Role of School Organization and Structure. American Educational Research Journal, 40(2), 353-393. http://doi.org/10.3102/00028312040002353

Lloyd, C. B., Mete, C., \& Grant, M. J. (2009). The implications of changing educational and family circumstances for children's grade progression in rural Pakistan: 1997-2004. Economics of Education Review, 28(1), 152-160. http://doi.org/10.1016/j.econedurev.2007.04.005

Mahler, S. J. (1999). Engendering Transnational Migration A Case Study Of Salvadorans. American Behavioral Scientist, 42(4), 690-719. http://doi.org/10.1177/00027649921954426

Maton, K., \& Moore, R. (Eds.). (2010). Social Realism, Knowledge and the Sociology of 
Education: Coalitions of the Mind. London, United Kingdom: Continnuum.

Mensch, B. S., \& Kandel, D. B. (1988). Underreporting of substance use in a national longitudinal youth cohort individual and interviewer effects. Public Opinion Quarterly, 52(1), 100-124.

Meyers, R., \& Houssemand, C. (2011). Teachers’ perception of school drop-out in Luxembourg. Procedia - Social and Behavioral Sciences, 15, 1514-1517. http://doi.org/10.1016/j.sbspro.2011.03.321

Ministry of Finance. (2014). Pakistan Economic Survey 2012-2013. Retrieved from http://www.finance.gov.pk/survey_1213.html

Munsaka, E. (2011). School Dropout: Are students to blame? LAP Lambert Academic Publishing.

National Assembly of Pakistan. (2012). The Constitution of the Islamic Republic of Pakistan. Retrieved from http://www.na.gov.pk/uploads/documents/1333523681_951.pdf

Natriello, G. (Ed.). (1987). School Dropouts: Patterns and Policies. Teachers' College Press, New York.

Pakistan Bureau of Statistics. (2011). Pakistan Social and Living Standards Measurement Survey (PSLM) 2010-11 Provincial / District. Retrieved from http://www.pbs.gov.pk/content/pakistan-social-and-living-standards-measurementsurvey-pslm-2010-11-provincial-district

Patterson, J. A., Hale, D., \& Stessman, M. (2007). Cultural contradictions and school leaving: A case study of an urban high school. The High School Journal, 91(2), 1-15.

Rumberger, R. W. (1987). High School Dropouts: A Review of Issues and Evidence. Review of Educational Research, 57(2), 101-121. http://doi.org/10.3102/00346543057002101

Rumberger, R. W., \& Lim, S. A. (2008). Why Students Drop Out of School: A Review of 25 Years of Research. California Dropout Research Project Report \#15.

Sabates, R., Akyeampong, K., Westbrook, J., \& Hunt, F. (2011). School Drop out : Patterns , Causes, Changes and Policies School Drop out: Patterns, Causes, Changes and Policies.

Sawada, Y. (1997). Human Capital Investments in Pakistan: Implications of Micro Evidence from Rural Households. The Pakistan Development Review, 36(4), 695-712.

Sawada, Y., \& Loksbin, M. (2001). Household Schooling Decisions in Rural Pakistan (No. Policy Research Workig Paper 4541). The World Bank.

Sawada, Y., \& Lokshin, M. (2009). Obstacles to school progression in rural Pakistan: An analysis of gender and sibling rivalry using field survey data. Journal of Development Economics, 88(2), 335-347. http://doi.org/10.1016/j.jdeveco.2008.03.002

Schargel, F., \& Smink, J. (2014). Strategies to Help Solve Our School Dropout Problem (1st ed.). Routledge.

Seidu, A., \& Adzahlie-Mensah, V. (2010). Teachers and Access to Schooling in Ghana. CREATE Pathways to Access Research Monograph No. 43. University of Sussex, UK.

Smyth, J., \& Hattam, R. (2002). Early School Leaving and the Cultural Geography of High Schools. British Educational Research Journal, 28(3), 375-397. http://doi.org/10.1080/0141192022013745

Stephens, D. (2000). Girls and basic education in Ghana : a cultural enquiry. International Journal of Educational Development, 20(1), 29-47. 
Stephens, D. (2000). Girls and Schooling in Developing Countries. International Journal of Educational Development, 20(1), 1-3. http://doi.org/10.1016/S0738-0593(99)00049-8

UNESCO Institute for Statistics (UIS). (2014). Progress in getting all children to school stalls but some countries show the way forward. Retrieved from http://unesdoc.unesco.org/images/0022/002281/228184E.pdf

UNICEF. (2013). Global Initiative on Out-of-School Children: Out-of-School Children in the Balochistan, Khyber Pakhtunkhwa, Punjab and Sindh Provinces of Pakistan. UNICEF Pakistan Country Office, Islamabad. Retrieved from http://allinschool.org/ 